\title{
Pengaruh Deposito Mudharabah dan NPF Terhadap ROA dan Pembiayaan Bagi Hasil Sebagai Intervening pada Bank Umum Syariah
}

The effect of mudharabah deposits and NPF on $\mathrm{RO} A$ and profit sharing financing as intervening in Islamic commercial banks

\section{Anggita Rismawati Rachman}

Program Studi D4 Keuangan Syariah, Politeknik Negeri Bandung

E-mail: anggitarismawati@gmail.com

\section{Benny Barnas}

Jurusan Akuntansi, Politeknik Negeri Bandung

E-mail: benny.barnas@polban.ac.id

\section{Ruhadi}

Jurusan Akuntansi, Politeknik Negeri Bandung

E-mail: ruhadi@polban.ac.id

\begin{abstract}
The researcher aims to discuss the factors that influence Return On Assets with the bank's internal variables as independent, namely Mudharabah Deposits, NPF and Profit Sharing Funding Value as intervening variables. To explain the direct and indirect effects of data analysis techniques used to use path analysis (Path Analysis) using SmartPLS 3.0 analysis software. The results showed that the Mudharabah Deposit had no effect, NPFt-1 had a negative effect and the Profit Sharing Funding Value had no effect on Return On Assets. Then Mudharabah Deposits do not have an effect on Return On Assets through Profit Sharing Financing V alue and NPFt-1 has no effect on Return On Assets through Profit Sharing Financing $V$ alue. The novelty of the study with previous research is the existence of an analysis to find out what factors influence $\mathrm{RO} A$ and $V$ alue of Financing Sharing as an intervening variable.
\end{abstract}

Keywords: return on asset, mudharabah deposits, non perfoming financing,profit sharing financing

\section{Pendahuluan}

Indonesia merupakan penduduk dengan mayoritas agama muslim terbesar di dunia dengan jumlah penduduk mencapai 87,2\% pada tahun 2016 (Badan Pusat Statistik, 2016). Dengan populasi muslim yang relatif besar, tidak menjamin terhadap dominan masyarakat terhadap perbankan syariah tinggi. Diharapkan perbankan syariah dapat memajukan perekonomian dan dapat bersaing dengan negara lain. Prasyarat perbankan syariah dapat eksis dan baik yaitu meningkatkan kinerja operasional perbankan syariah. Meningkatnya kualitas kinerja keuangan dapat menjadi salah satu ciri perbankan yang sehat dan mengakibatkan perekonomian negara menjadi sehat dan berkembang. Penilaian kinerja keuangan perbankan dapat dilihat dari aspek rasio profitabilitas yaitu Return on Asset (ROA).

Return on Assets merupakan salah satu rasio profitabilitas yang berfungsi untuk mengetahui kemampuan bank dalam mengelola dana dalam asset yang dimiliki perusahaan dan bernilai keuntungan. Semakin besar nilai rasio ROA, semakin besar keuntungan dan optimal kegiatan yang 
dilakukan bank. Kriteria penilaian ROA menurut Bank Indonesia mengatakan bahwa suatu perbankan dapat dikatakan berkriteria bank yang sehat jika ROA lebih besar sama dengan 1,5\%. Berikut merupakan ROA Bank Umum Syariah pada tahun 2012-2018.

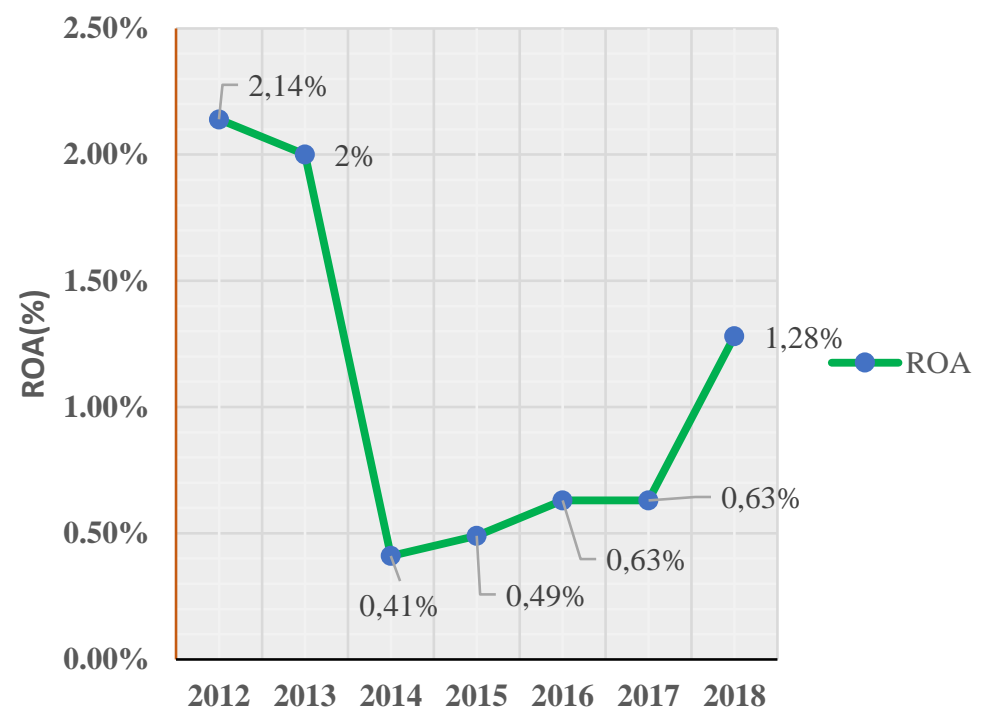

Gambar 1. Grafik Return on Asset pada BUS

Berdasarkan data diatas, ROA pada tahun 2014-2015 sebesar 0,41\% dan 0,49\% dimana menurut kriteria dari Bank Indonesia ROA tersebut termasuk kategori bank syariah yang kurang sehat. Lalu pada tahun 2016-2017 ROA stagnan sebesar 0,63\% dimana kategori tersebut termasuk kategori cukup. Kriteria penilaian ROA menurut Bank Indonesia mengatakan bahwa suatu perbankan dapat dikatakan berkriteria bank yang sehat jika ROA lebih besar sama dengan 1,5\%. Maka perbankan syariah di Indonesia perlu meningkatkan ROA agar dapat termasuk kategori yang sehat dan dapat bersaing dengan negara lain.

Usaha yang dilakukan oleh bank syariah agar dapat meningkatkan keuntungan yaitu dengan menyalurkan pembiayaan yang bersifat produktif yaitu pembiayaan bagi hasil berakad Mudharabah dan Musyarakah. Pembiayaan berakad bagi hasil menerapkan sistem saling membagi keuntungan dan resiko sesuai dengan porsi masing-masing. Pembiayaan bagi hasil dapat mendorong perekonomian lebih berkembang karena terjadinya aktivitas ekonomi riil, selain itu juga peluang untuk membuka lapangan pekerjaan baru meningkat.

Perkembangan pembiayaan bank syariah yang terjadi kini di beberapa negara muslim termasuk Indonesia lebih didominasi oleh skema berakad murabahah mencapai 70\% (Dewi dan Setyowati, 2017). Rendahnya pembiayaan bagi hasil dapat membuat persepsi publik bahwa bank syariah hamper tidak memiliki perbedaan dengan bank konvensional (Ascarya dan Yumanita, 2005). Maka perbankan syariah seharusnya dapat mengaplikasikan pembiayaan bagi hasil yang lebih mendominasi dibandingkan pembiayaan murabahah.

Di antara penelitian terkait adalah penelitian oleh Yunita Agza (2016) dalam jurnal yang berjudul "Pengaruh pembiayaan Murabahah dan Musyarakah terhadap ROA pada BPRS" menyatakan bahwa pembiayaan musyarakah berpengaruh secara signifikan terhadap ROA. Dan penelitian oleh Dila Angraini (2018) menyatakan bahwa pembiayaan bagi hasil memiliki pengaruh signifikan terhadap profitabilitas yang diproyeksikan oleh ROA. Namun beda halnya dengan hasil penelitian oleh Ian dan Arim (2016) yang berjudul "Pengaruh Pembiayaan Jual Beli, Pembiayaan Bagi Hasil, dan NPF terhadap Profitabilitas Studi pada BUS" yang menyatakan bahwa Pembiayaan Bagi Hasil berpengaruh negatif signifikan terhadap ROA. 
Oleh karena itu, perlu dikaji mengenai faktor-faktor yang mempengaruhi Return on Asset melalui Nilai Pembiayaan Bagi Hasil, dimana faktor -faktor yang mempengaruhi pembiayaan bagi hasil dikaji untuk dapat mendorong peningkatan pembiayaan bagi hasil yang berimplikasi pada ROA. Beberapa faktor tersebut adalah Deposito Mudharabah dan NPF.

\section{Kajian Pustaka}

\subsection{Pengaruh Deposito Mudharabah terhadap Nilai Pembiayaan Bagi Hasil}

Deposito mudharabah yaitu investasi melalui simpanan pihak ketiga (perseorangan atau badan hukum) yang penarikannya hanya dapat dilakukan dalam jangka waktu tertentu sesuai dengan perjanjian nasabah dengan penyimpan akad mudharabah dimana pembagian keuntungan antara nasabah dengan bank sesuai dengan bagi hasil (Juniarty dkk., 2017). Dana pihak ketiga yang berasal dari Deposito Mudharabah lebih disukai oleh bank dikarenakan bank dapat lebih leluasa dalam menyalurkan pembiayaan karena dana yang diinvestasikan oleh nasabah relatif lebih panjang dan tidak likuid. Sehinga bank syariah lebih leluasa menyalurkan pembiayaan bagi hasil.

H1 = Deposito Mudharabah diduga mempunyai pengarub positif terbadap Nilai Pembiayaan Bagi Hasil pada BUS.

\subsection{Pengaruh Non Perfoming Financing t-1 terhadap Nilai Pembiayaan Bagi Hasil}

Rasio NPF yang semakin besar menunjukkan bahwa bank belum mampu mengelola pembiayaan yang disalurkan secara baik dalam arti masih banyak pembiayaan bermasalah yang terjadi dalam manajemen bank, sehingga bank mengalami kesulitan operasional (Hijriyani dan Setiawan, 2017). Pembiayaan kualitas buruk tahun sebelumnya memerlukan cadangan penghapusan aktiva produktif yang semakin besar, sehingga menyebabkan biaya yang ditanggung untuk mengadakan cadangan tersebut semakin besar pula. Jika hal ini terjadi terus menerus, dapat memengaruhi kemampuan bank dalam menyalurkan pembiayaan, termasuk pembiayaan berbasis bagi hasil. Maka diperlukan pengendalian dalam pembuatan kebijakan untuk memperketat aturan pengelolaan penyaluran pembiayaan (Nur'aeni dan Setiawan, 2020).

H2=Non Perfoming Financing t-1 diduga mempunyai pengarub negatif terhadap Nilai Pembiayaan Bagi Hasil pada BUS.

\subsection{Pengaruh Deposito Mudharabah terhadap Return On Asset}

Dana deposito Mudharabah yang dihimpun dari masyarakat merupakan sumber dana yang memiliki jumlah nominal terbesar dan porsi yang digunakan untuk menyalurkan pembiayaan dominan oleh Deposito Mudharabah. Bank dapat memanfaatkan dana deposito mudharabah ini untuk ditempatkan pada pos-pos yang menghasilkan pendapatan bagi bank, salah satunya yaitu dalam bentuk pembiayaan.

H3 = Deposito Mudharabah diduga mempunyai pengarub positif terbadap Return On Asset pada BUS

\subsection{Pengaruh Non Perfoming Financing t-1 terhadap Return On Asset}

Semakin kecil nilai NPF tahun lalu menunjukkan efektivitas bank dalam menyalurkan pembiayaan berkualitas saat ini semakin baik sehingga perputaran uang untuk menghasilkan profit akan semakin tinggi. Selain itu NPF tahun lalu yang rendah akan semakin kecil pula beban pencadangan piutang aktiva produktif (PPAP). Dengan adanya penurunan cadangan piutang aktiva produktif (PPAP) akan mengakibatkan kenaikan return on asset (ROA) (Mahmoeddin, 2010).

H4=Non Perfoming Financing tabun lalu diduga mempunyai pengarub negatif terbadap Return On Asset pada $B U S$.

\subsection{Pengaruh Nilai Pembiayaan Bagi Hasil terhadap Return On Asset}

Nilai Pembiayaan Bagi Hasil merupakan salah satu komponen penyusunan asset pada 
perbankan syariah. Dengan adanya peningkatan nilai pembiayaan yang disalurkan, terutama pada pembiayaan sektor produktif agar tingkat pengembalian modal dan pencapaian bagi hasil terjamin. Semakin besar nilai transaksi pembiayaan yang disalurkan, maka akan semakin besar tingkat bagi hasil maupun margin keuntungan yang akan diterima oleh Bank Syariah. Keuntungan yang diukur menggunakan sejumlah aset yang dimiliki oleh bank dapat diukur dengan rasio ROA.

\subsection{Pengaruh Deposito Mudharabah terhadap Return On Asset melalui Nilai Pembiayaan Bagi Hasil}

Deposito Mudharabah merupakan salah satu bentuk dari dana pihak ketiga yang memiliki jumlah nominal terbesar dan porsi dana pembiayaan terbesar. Deposito termasuk investasi jangka panjang dimana dana yang diivestasikan mengendap dalam jangka waktu yang relatif lebih panjang maka Bank syariah lebih leluasa dalam menyalurkan pembiayaan kepada nasabah. Maka dapat disimpulkan bahwa semakin tinggi Deposito Mudharabah maka akan menyebabkan Pembiayaan Bagi Hasil semakin banyak, dan menyebabkan keuntungan yang diperoleh semakin tinggi yang dapat diproyeksikan oleh Return On Asset (ROA) bank akan meningkat.

\subsection{Pengaruh Non Perfoming Financing t-1 terhadap Return On Asset melalui Nilai Pembiayaan Bagi Hasil}

Non Perfoming Financing (NPF) yaitu salah satu indikator yang menunjukan risiko pembiayaan gagal membayar sebagian atau seluruh kewajiban pembiayaan kepada bank sesuai dengan jangka waktu yang ditetapkan. Semakin kecil nilai NPF tahun sebelumnya menunjukkan efektivitas bank dalam menyalurkan pembiayaan berkualitas semakin besar sehingga perputaran uang untuk menghasilkan profit akan semakin tinggi. Selain itu NPFt-1 yang rendah akan semakin kecil pula beban pencadangan piutang aktiva produktif (PPAP). Dengan adanya penurunan cadangan piutang aktiva produktif (PPAP) akan mengakibatkan kenaikan return on asset (ROA) (Mahmoeddin, 2010).

\section{Metode Penelitian}

Populasi dalam penelitian ini adalah laporan keuangan tahunan Bank Umum Syariah. Pemilihan sampel dilakukan dengan menggunakan metode purposive sampling yaitu metode penentuan responden untuk dijadikan sampel berdasarkan kriteria tertentu. (Siregar, 2015). Sampel dalam penelitian ini adalah 9 Bank Umum Syariah dan data dalam bentuk tahunan periode 2012 sampai 2018 yang berjumlah 63 data.

Peneliti menggunakan analisis jalur (Path Analysis) dikarenakan untuk mengetahui hubungan sebab akibat, dengan tujuan menerangkan pengaruh langsung atau tidak langsung antar variabel eksogen dengan variabel endogen. Teknik analisis data yang digunakan yaitu metode deksriptif kuantitatif yaitu data-data yang berupa angka dikumpulkan dan dianalisis berdasarkan metode yang telah ditentukan yang bertujuan untuk mengetahui bagaimana pengaruh masing masing variabel. Software pengolahan data dalam penelitian ini menggunakan bantuan software Smart Partial Least Square (SmartPLS) versi 3.0

\section{Hasil dan Pembahasan}

\subsection{Pengujian Model Pengukuran (Outer Model)}

Outer Model dapat memastikan bahwa measurement layak dijadikan pengukuran dalam penelitian (valid dan reliable). Outer Model melalui dua tahap uji yaitu Uji Validitas dan Uji Reliabilitas.

\footnotetext{
1. Uji Validitas

untuk mengetahui seberapa tepat suatu tes melakukan fungsinya. Semakin tinggi validitas suatu fungsi ukur, semakin tinggi juga pengukuran mendekati sasarannya ( Sekaran, 2003).

a. Convergent Validity
} 
Nilai Convergent Validity merupakan indikator yang dinilai berdasarkan korelasi antara component score dengan construct score, yang dapat dilihat dari loading factor dan AVE. Penelitian disebut valid apabila nilai loading factor $>0,7$ dan nilai Average variance extracted (AVE) $>0,5$.

Tabel 1. Convergent V alidity

\begin{tabular}{|c|c|c|c|c|}
\hline Variabel & $\begin{array}{c}\text { Loading } \\
\text { Factor }\end{array}$ & AVE & $\begin{array}{c}\text { Hasil Pengujian } \\
\text { Loading Factor }\end{array}$ & $\begin{array}{c}\text { Hasil Pengujian } \\
\text { AVE }\end{array}$ \\
\hline Deposito Mudharabah & 1.000 & 1.000 & Valid $(>0,70)$ & Valid $(>0,50)$ \\
\hline NPFt-1 & 1.000 & 1.000 & Valid $(>0,70)$ & Valid $(>0,50)$ \\
\hline Nilai Pembiayaan Bagi Hasil & 1.000 & 1.000 & Valid $(>0,70)$ & Valid $(>0,50)$ \\
\hline ROA & 1.000 & 1.000 & Valid $(>0,70)$ & Valid $(>0,50)$ \\
\hline
\end{tabular}

Berdasarkan hasil pengujian Convergent Validity pada tabel maka dapat dijelaskan sebagai berikut :

a. Variabel Deposito Mudharabah memiliki nilai loading factor 1.000 atau $>0,70$ dan nilai AVE yaitu 1.000 atau $>0,50 \mathrm{Hal}$ ini menunjukan bahwa variabel Deposito Mudharabah dinyatakan valid dan dapat dilakukan untuk pengujian penelitian.

b. Variabel NPFt-1 memiliki nilai loading factor 1.000 atau $>0,70$ dan nilai AVE yaitu 1.000 atau $>0,50$. Hal ini menunjukan bahwa variabel NPFt-1 dinyatakan valid dan dapat dilakukan untuk pengujian penelitian.

c. Variabel Nilai Pembiayaan Bagi Hasil memiliki nilai loading factor 1.000 atau $>0,70$ dan nilai AVE yaitu 1.000 atau $>0,50$. Hal ini menunjukan bahwa variabel Nilai Pembiayaan Bagi Hasil dinyatakan valid dan dapat dilakukan untuk pengujian penelitian.

d. Variabel ROA emiliki nilai loading factor 1.000 atau $>0,70$ dan nilai AVE yaitu 1.000 atau $>$ 0,50. Hal ini menunjukan bahwa variabel ROA dinyatakan valid dan dapat dilakukan untuk pengujian penelitian.

\section{a. Discriminant Validity}

Discriminant V alidity untuk mengetahui bahwa setiap konstruknya memiliki nilai diskriminan yang memadai yaitu dengan cara membandingkan nilai loading pada konstruk yang dituju harus lebih besar dibandingkan nilai loading dengan konstruk lain. Maka dapat tercermin bahwa setiap variabel yang mempengaruhinya telah mewakili variabel laten dan menjadi konstruk yang baik.

Tabel 1. Discriminant Validity

\begin{tabular}{|c|c|c|c|c|}
\hline Cross Loadings & Deposito & NPFt-1 & $\mathrm{ROA}$ & $\begin{array}{l}\text { Nilai Pembiayaan } \\
\text { Bagi Hasil }\end{array}$ \\
\hline Nilai Pembiayaan Bagi Hasil & 0,429 & 0,246 & 0,113 & 1.000 \\
\hline Deposito & 1.000 & 0,185 & $-0,031$ & 0,429 \\
\hline NPFt-1 & 0,185 & 1.000 & $-0,280$ & 0,246 \\
\hline ROA & $-0,031$ & $-0,280$ & 1.000 & 0,113 \\
\hline
\end{tabular}

Pada tabel dapat dilihat bahwa setiap variabel terhadap variabel latennya memiliki nilai yang lebih besar dibandingkan dengan variabel lainnya sehingga memiliki keterkaitan yang baik. Hal ini dapat dijelaskan sebagai berikut :

a. Variabel laten Deposito Mudharabah terhadap Deposito Mudharabah memiliki nilai cross loading sebesar 1.000 dimana hasil tersebut lebih besar dibandingkan Variabel laten Deposito Mudharabah terhadap variabel selain variabel laten yaitu NPF, ROA dan Nilai Pembiayaan Bagi Hasil.

b. Variabel NPFt-1 terhadap NPFt-1 memiliki nilai cross loading sebesar 1.000 dimana hasil tersebut lebih besar dibandingan variabel laten NPFt-1 terhadap variabel selain variabel laten. 
c. Begitu pula dengan Variabel ROA dan Nilai Pembiayaan Bagi Hasil memiliki indicator yang lebih tinggi terhadap variabel latennya yaitu sebesar 1.000 Pengukuran Discriminant Validity ini memastikan bahwa variabel yang mempengaruhi variabel latennya telah memenuhi atau mewakili variabel latennya dan menjadi konstruk yang baik.

\section{Uji Reliabilitas}

Uji Reliabilitas bertujuan untuk mengetahui suatu instrumen cukup dipercaya untuk digunakan sebagai alat pengumpul data karena instrumen tersebut sudah baik (Arikunto, 1996). Reliabilitas juga digunakan sebagai ukuran suatu hasil pengukuran relatif konsisten apabila pengukuran diulang lebih dari dua kali atau lebih. Pengujian ini dapat dilihat berdasarkan nilai Composite Reliability. Konstruk dapat dinilai sudah reliabel (dapat dipercaya) apabila nilai composite reliability $\geq 0,70$.

Tabel 3. Composite Reliability

\begin{tabular}{|c|c|}
\hline & $\begin{array}{c}\text { Composite } \\
\text { Reliability }\end{array}$ \\
\hline Deposito & 1.000 \\
\hline NPFt-1 & 1.000 \\
\hline $\begin{array}{c}\text { Nilai Pembiayaan Bagi } \\
\text { Hasil }\end{array}$ & 1.000 \\
\hline ROA & 1.000 \\
\hline
\end{tabular}

Berdasarkan tabel tersebut dapat disimpulkan bahwa variabel Deposito Mudharabah, NPFt1, Nilai Pembiayaan Bagi Hasil dan ROA memiliki nilai Composite Reliability sebesar 1 yang merupakan $>0,70$. Hal ini menunjukan bahwa seluruh variabel reliable atau dapat dipercaya untuk penelitian.

\section{A. Pengujian Model Struktural (Inner Model)}

Model structural bertujuan untuk mengetahui hubungan antara variabel dengan melihat nilai koefisien parameter path dan siginfikansinya. Pengujian model inner model dapat dilihat berdasarkan nilai R-square. Nilai R-Square digunakan untuk mengetahui pengaruh variabel independen terhadap variabel dependen apakah memiliki pengaruh yang substantif

Tabel 4. Inner Model

\begin{tabular}{|c|c|}
\hline & R square \\
\hline ROA & 0.117 \\
\hline $\begin{array}{c}\text { Nilai Pembiayaan Bagi } \\
\text { Hasil }\end{array}$ & 0.213 \\
\hline
\end{tabular}

Pada tabel dapat dilihat bahwa nilai R-square untuk Nilai Pembiayaan Bagi Hasil sebesar 0,213 yang berarti bahwa 21,3\% dari Nilai Pembiayaan Bagi Hasil dipengaruhi oleh variabel independen berupa Deposito Mudharabah dan NPF. Sedangkan nilai R-square terhadap Return On Asset atau ROA memiliki pengaruh sebesar 0,117 yang berarti 11,7\% dari ROA dipengaruhi oleh variabel independen berupa Deposito Mudharabah,NPF dan Nilai Pembiayaan Bagi Hasil dan sisanya sebesar $78,7 \%$ dipengaruhi oleh faktor lain yang tidak masuk dalam variabel penelitian.

\section{B. Pengujian Hipotesis}

Dalam penelitian untuk menguji hipotesis maka dapat dilihat dari nilai yang terdapat pada output path coefficient. Nilai yang dilihat dari output path coefficient ini bertujuan untuk melihat ukuran signifikansi dalam hipotesis. Apabila nilai T-statistics $>1,96$ dan P-values $<0,05$ maka hipotesis 
terdukung diterima.

Tabel dibawah ini merupakan hasil pengujian hipotesis menggunakan perhitungan P-values dan koefisien korelasi sebagai berikut :

Tabel 5. Path Coefficient

\begin{tabular}{|c|c|c|c|c|}
\hline & $\begin{array}{c}\text { Original } \\
\text { Sample (O) }\end{array}$ & $\begin{array}{c}\text { T Statistics } \\
(\mid \mathbf{O} / \text { STDEV|) }\end{array}$ & P Values & Keterangan \\
\hline $\begin{array}{c}\text { Deposito M -> Nilai } \\
\text { Pembiayaan Bagi Hasil }\end{array}$ & 0.397 & 2.698 & 0.007 & $\begin{array}{c}\text { Berpengaruh Positif } \\
\text { Signifikan }\end{array}$ \\
\hline $\begin{array}{c}\text { NPFt-1-> Nilai Pembiayaan } \\
\text { Bagi Hasil }\end{array}$ & 0.172 & 1.748 & $\mathbf{0 . 0 8 1}$ & $\begin{array}{c}\text { Tidak Berpengaruh } \\
\text { Signifkan }\end{array}$ \\
\hline Deposito M-> ROA & -0.066 & 0.916 & $\mathbf{0 . 3 6 0}$ & $\begin{array}{c}\text { Tidak Berpengaruh } \\
\text { Signifikan }\end{array}$ \\
\hline NPFt-1 -> ROA & -0.322 & 2.731 & $\mathbf{0 . 0 0 7}$ & $\begin{array}{c}\text { Berpengaruh } \\
\text { Negatif Signifikan }\end{array}$ \\
\hline $\begin{array}{c}\text { Nilai Pembiayaan Bagi } \\
\text { Hasil> ROA }\end{array}$ & 0.220 & 1.653 & $\mathbf{0 . 0 9 9}$ & $\begin{array}{c}\text { Tidak Berpengaruh } \\
\text { Signifikan }\end{array}$ \\
\hline
\end{tabular}

Berdasarkan tabel maka hasil hipotesis penelitian ini dapat dijabarkan sebagai berikut:

1. Diketahui dalam tabel bahwa variabel Deposito Mudharabah terhadap Nilai Pembiayaan Bagi Hasil memiliki sampel asli adalah sebesar 0.397 (positif) dan nilai p-values sebesar 0.007 yang mana nilai ini $<0.05$ dan $T$ statistic sebesar $2.698>1.96$. Dapat disimpulkan bahwa Deposito Mudharabah memiliki pengaruh positif signifikan terhadap Nilai Pembiayaan Bagi Hasil. Maka Hipotesis 1 diterima.

2. Diketahui dalam tabel bahwa variabel NPFt-1 terhadap Nilai Pembiayaan Bagi Hasil memiliki sampel asli adalah 0.172 (positif) dan nilai p-values sebesar 0.0081 yang mana nilai ini $>0.05$ dan T statistic sebesar $1.748<1.96$. Dapat disimpulkan bahwa NPFt-1 tidak berpengaruh signifikan terhadap Nilai Pembiayaan Bagi Hasil. Maka Hipotesis 2 ditolak.

3. Diketahui dalam tabel bahwa variabel Deposito Mudharabah terhadap Return On Asset memiliki sampel asli adalah sebesar -0.066 (negatif) dan nilai p-values sebesar 0.360 yang mana nilai ini $>0.05$ dan T statistic sebesar $0.916<1.96$. Dapat disimpulkan bahwa Deposito Mudharabah tidak berpengaruh signifikan terhadap Return On Asset. Maka Hipotesis 3 ditolak.

4. Diketahui dalam tabel bahwa variabel NPFt-1 terhadap Return On Asset memiliki sampel asli adalah -0.322 (negatif) dan nilai $\mathrm{p}$-values sebesar 0.007 yang mana nilai ini $<0.05$ dan $\mathrm{T}$ statistic sebesar $2.731>1.96$. Dapat disimpulkan bahwa NPFt-1 berpengaruh negatif terhadap Return On Asset. Maka Hipotesis 4 diterima.

5. Diketahui dalam tabel bahwa variabel Nilai Pembiayaan Bagi Hasil terhadap Return On Asset memiliki sampel asli adalah sebesar 0.220 (positif) dan nilai p-values sebesar 0.099 yang mana nilai ini $>0.05$ dan T statistic sebesar $1.653<1.96$. Dapat disimpulkan bahwa variabel Nilai Pembiayaan Bagi Hasil memiliki tidak berpengaruh signifikan terhadap Return On Asset. Maka Hipotesis 5 ditolak

Tabel 6. Indirect Effects

\begin{tabular}{|c|c|c|c|c|}
\hline Specific Indirect Effects & $\begin{array}{c}\text { Original } \\
\text { Sample (O) }\end{array}$ & $\begin{array}{c}\text { T Statistics } \\
(\mid \mathbf{O} / \text { STDEV } \mid)\end{array}$ & P Values & Keterangan \\
\hline $\begin{array}{c}\text { Deposito M -> Nilai } \\
\text { Pembiayaan Bagi Hasil } \\
\text {-> ROA }\end{array}$ & 0.087 & 1.327 & 0.185 & $\begin{array}{c}\text { Tidak Berpengaruh } \\
\text { Signifikan }\end{array}$ \\
\hline
\end{tabular}




\begin{tabular}{|c|c|c|c|c|}
\hline Specific Indirect Effects & $\begin{array}{c}\text { Original } \\
\text { Sample (O) }\end{array}$ & $\begin{array}{c}\text { T Statistics } \\
(\mid \mathbf{O} / \text { STDEV } \mid)\end{array}$ & P Values & Keterangan \\
\hline $\begin{array}{c}\text { NPFt-1 -> Nilai } \\
\text { Pembiayaan Bagi Hasil } \\
\text {-> ROA }\end{array}$ & 0.038 & 1.168 & 0.243 & $\begin{array}{c}\text { Tidak Berpengaruh } \\
\text { Signifikan }\end{array}$ \\
\hline
\end{tabular}

1. Diketahui dalam tabel bahwa variabel Deposito Mudharabah terhadap Return On Asset melalui Nilai Pembiayaan Bagi Hasil memiliki sampel asli adalah sebesar 0.087 (positif) dan nilai $\mathrm{p}$-values sebesar 0.185 yang mana nilai ini $>0.05$ dan $T$ statistic sebesar $1.327<1.96$. Dapat disimpulkan bahwa Deposito Mudharabah tidak berpengaruh terhadap Return On Asset melalui Nilai Pembiayaan Bagi Hasil. Maka Hipotesis 6 ditolak

2. Diketahui dalam tabel bahwa variabel NPFt-1 terhadap Return On Asset melalui Nilai Pembiayaan Bagi Hasil memiliki sampel asli adalah 0.038 (positif) dan nilai p-values sebesar 0.243 yang mana nilai ini $>0.05$ dan T statistic sebesar $1.168<1.96$. Dapat disimpulkan bahwa NPFt-1 tidak berpengaruh terhadap Return On Asset melalui Nilai Pembiayaan Bagi Hasil. Maka Hipotesis 7 ditolak.

\subsection{Pembahasan Hasil Penelitian}

\section{Pengaruh Deposito Mudharabah terhadap Nilai Pembiayaan Bagi Hasil}

Hipotesis 1 yang diajukan pada penelitian ini adalah Deposito Mudharabah diduga mempunyai pengaruh positif terhadap Nilai pembiayaan bagi hasil. Hasil uji statistik menunjukkan bahwa nilai variabel Deposito Mudharabah terhadap Nilai Pembiayaan Bagi Hasil memiliki koefisien regresi/ original sample adalah sebesar 0.397 (positif) dan nilai p-values sebesar 0.007 yang mana nilai ini $<0.05$ dan $T$ statistik sebesar $2.698>1.96$. Oleh karena nilai p-values kurang dari 0,05 maka Hipotesis 1 dapat diterima. Hasil ini menunjukan bahwa jika Deposito Mudharabah mengalami kenaikan sebesar 1 satuan, maka Nilai Pembiayaan Bagi Hasil akan mengalami kenaikan sebesar 0,397 satuan.

Karena dana pihak ketiga yang berupa deposito mudharabah memiliki jumlah nominal yang paling besar dan memiliki porsi komposisi dana terbesar sebanyak 59\% yang akan disalurkan dalam bentuk pembiayaan oleh bank. Selain itu deposito mudharabah merupakan simpanan bersifat jangka panjang yang penarikannya hanya dapat dilakukan sesuai dengan perjanjian nasabah dengan bank. Deposito mudharabah memiliki tingkat likuiditas lebih rendah dibandingkan dengan tabungan dan giro.

Penelitian ini sejalan dengan penelitian yang dilakukan oleh Maryanah (2006), Andraeny (2011), John (2014) dan Dila (2018) menyatakan bahwa semakin banyak dana pihak ketiga terhimpun yaitu deposito mudharabah maka semakin besar Nilai Pembiayaan Bagi Hasil yang akan disalurkan oleh bank

\section{Pengaruh NPFt-1 terhadap Nilai Pembiayaan Bagi Hasil}

Hipotesis 2 yang diajukan pada penelitian ini adalah NPF tahun lalu diduga mempunyai pengaruh negatif terhadap Nilai pembiayaan bagi hasil. Dalam hasil penelitian menunjukan bahwa variabel NPF tahun lalu secara parsial tidak memiliki pengaruh signifikan dan bernilai positif terhadap Nilai pembiayaan bagi hasil pada Bank Umum Syariah di Indonesia.

Hasil uji statistik menunjukkan bahwa NPF tahun lalu terhadap Nilai Pembiayaan Bagi Hasil memiliki koefisien regresi/ original sample adalah sebesar 0.172 (positif) dan nilai p-values sebesar 0.081 yang mana nilai ini $>0.05$ dan T statistik sebesar $1.748<1.96$. Oleh karena nilai $\mathrm{p}$-values lebih besar dari 0,05 maka Hipotesis 2 dapat ditolak. Hasil ini menunjukan bahwa NPF tahun lalu jika mengalami kenaikan sebesar 1 satuan, maka Nilai Pembiayaan Bagi Hasil akan mengalami 
kenaikan sebesar 0.172 satuan. Maka dapat dikatakan bahwa tidak terdapat pengaruh signifikan antara NPF tahun lalu terhadap Nilai Pembiayaan Bagi Hasil Bank Umum Syariah.

Hal ini dikarenakan NPFt-1 tersebut merupakan rasio pembiayaan bermasalah berakad total yang mencakup pembiayaan bermasalah berakad murabahah, mudharabah, musyarakah, ijarah dan istishna maka apabila terjadi peningkatan NPF tahun lalu maka akan menurunkan jumlah pembiayaan murabahah. Dikarenakan pembiayaan yang memiliki porsi pembiayaan yang paling dominan mencapai sekitar 55\%-60\% dari total pembiayaan. Sedangkan nilai pembiayaan berakad bagi hasil (mudharabah dan musyarakah) berjumlah sekitar 20-29\% dari total volume pembiayaan. Maka pembiayaan bermasalah yang semakin meningkat akibat dari nilai pembiayaan murabahah yang semakin besar dan mengakibatkan NPFt-1 tidak berpengaruh terhadap Nilai Pembiayaan Bagi Hasil.

Hal ini sesuai dengan penelitian Andraeny (2011) yang menyatakan bahwa NPF tahun lalu tidak berpengaruh terhadap volume pembiayaan berbasis bagi hasil. Selain itu penelitian Herni Ali (2015) juga menyatakan bahwa NPF tahun lalu tidak berpengaruh terhadap nilai pembiayaan berbasis bagi hasil.

\section{Pengaruh Deposito Mudharabah terhadap Return On Asset}

Hipotesis 3 yang diajukan pada penelitian ini adalah Deposito Mudharabah diduga mempunyai pengaruh positif terhadap Return on Asset. Dalam hasil penelitian menunjukan bahwa variabel Deposito Mudharabah secara parsial tidak berpengaruh signifikan terhadap Return on Asset pada Bank Umum Syariah di Indonesia.

Hasil uji statistik menunjukkan bahwa nilai variabel Deposito Mudharabah terhadap Return on Asset memiliki koefisien regresi/ original sample adalah sebesar

$-0,066$ (negatif) dan nilai $\mathrm{p}$-values sebesar 0.360 yang mana nilai ini $>0.05$ dan $T$ statistik sebesar $0.916<1.96$. Oleh karena nilai p-values lebih besar dari 0,05 maka Hipotesis 3 ditolak. Hasil ini menunjukan bahwa jika Deposito Mudharabah mengalami kenaikan sebesar 1 satuan, maka Return on Asset akan mengalami penurunan sebesar 0,066 satuan. Maka dapat dikatakan bahwa tidak terdapat pengaruh signifikan antara Deposito Mudharabah terhadap Return on Asset Bank Umum Syariah.

Hal ini dikarenakan dalam Deposito Mudharabah merupakan salah satu bentuk dana pihak ketiga yang dihimpun dari masyarakat menggunakan akad mudharabah dimana Bank Syariah mengelola dana yang dihimpun nasabah untuk disaurkan kembali dalam bentuk pembiayaan dan Bank memberikan bagi hasil kepada nasabah, dimana porsi bagi hasil yang diterima Bank Syariah tidak banyak dan signifikan yang mengakibatkan keuntungan Bank dalam bentuk Return On Asset pun tidak signifikan. Maka Deposito Mudharabah tidak berpengaruh secara langsung terhadap Return On Asset.

Penelitian ini didukung oleh Kurniawan (2012) yang menyatakan bahwa dana pihak ketiga secara parsial berpengaruh tidak signifikan terhadap ROA. Dan hasil penelitian dari Mukarromah dan Badjra (2015) menyatakan bahwa deposito tidak berpengaruh terhadap profitabilitas.

\section{Pengaruh NPFt-1 terhadap Return On Asset}

Hipotesis 4 yang diajukan pada penelitian ini adalah NPF tahun lalu diduga mempunyai pengaruh negatif terhadap Return On Asset. Dalam hasil penelitian menunjukan bahwa variabel NPF tahun lalu secara parsial memiliki pengaruh negative signifikan terhadap Return On Asset pada Bank Umum Syariah di Indonesia.

Hasil uji statistik menunjukkan bahwa NPF tahun lalu terhadap Return On Asset memiliki koefisien regresi / original sample adalah sebesar - 0.322 (negatif) dan nilai $\mathrm{p}$-values sebesar 0.007 yang mana nilai ini $<0.05$ dan T statistik sebesar $2.731>1.96$. Oleh karena nilai p-values lebih 
kecil dari 0,05 maka Hipotesis 4 diterima. Hasil ini menunjukan bahwa NPF tahun lalu jika mengalami kenaikan sebesar 1 satuan, maka Return On Asset akan mengalami penurunan sebesar 0.322 satuan. Maka dapat dikatakan bahwa terdapat pengaruh negative signifikan antara NPF tahun lalu terhadap Return On Asset Bank Umum Syariah.

Hal ini dikarenakan bahwa NPF tahun lalu sesuai dengan fenomena yang terjadi pada perbankan syariah dimana NPF tahun lalu tersebut merupakan rasio yang digunakan untuk mengukur kemampuan manajemen bank dalam mengelola pembiayaan bermasalah. Semakin besar nilai NPF tahun lalu menunjukkan efektivitas bank dalam menyalurkan pembiayaan berkualitas semakin buruk sehingga perputaran uang untuk menghasilkan profit akan semakin rendah. Selain itu dengan NPF tahun lalu yang tinggi maka semakin besar pula beban pencadangan piutang aktiva produktif (PPAP). Dengan adanya kenaikan cadangan piutang aktiva produktif (PPAP) akan mengakibatkan penurunan ROA (Mahmoeddin, 2010).

Penelitian ini didukung oleh penelitian sebelumnya yaitu Ratu Edo dan Wiagustini (2014), Ian dan Arim (2016), Yuhanah (2016) dan Angraini (2018) menyatakan bahwa NPF tahun lalu berpengaruh negatif dan signifikan terhadap ROA.

\section{Pengaruh Nilai Pembiayaan Bagi Hasil terhadap Return On Asset}

Hipotesis 5 yang diajukan pada penelitian ini adalah Nilai Pembiayaan Bagi Hasil memiliki pengaruh positif terhadap Return On Asset. Dalam hasil penelitian menunjukan bahwa variabel Nilai Pembiayaan Bagi Hasil secara parsial tidak berpengaruh signifikan terhadap Return On Asset pada Bank Umum Syariah di Indonesia.

Hasil uji statistik menunjukkan bahwa Nilai Pembiayaan Bagi Hasil terhadap Return On Asset memiliki koefisien regresi /original sample adalah sebesar 0.220 (positif) dan nilai p-values sebesar 0.099 yang mana nilai ini $>0.05$ dan $\mathrm{T}$ statistik sebesar $1.653<1.96$. Oleh karena nilai $\mathrm{p}$-values lebih besar dari 0,05 maka Hipotesis 4 ditolak. Hasil ini menunjukan bahwa Nilai Pembiayaan Bagi Hasil jika mengalami kenaikan sebesar 1 satuan, maka Return On Asset akan mengalami kenaikan sebesar 0.22 satuan. Maka dapat dikatakan bahwa tidak terdapat pengaruh signifikan antara Nilai Pembiayaan Bagi Hasil terhadap Return On Asset Bank Umum Syariah.

Hal ini dikarenakan bahwa Nilai Pembiayaan Bagi Hasil sesuai dengan fenomena yang terjadi pada perbankan syariah dimana Jumlah porsi pembiayaan bagi hasil yang disalurkan oleh bank syariah hanya berkisar 25\%-29\%. Pembiayaan tersebut masih lebih sedikit dibandingkan pembiayaan murabahah. Bank Syariah kurang menyalurkan pembiayaan bagi hasil dikarenakan pembiayaan bagi hasil merupakan pembiayaan Natural Uncertainty Contract yaitu kontrak pembiayaan yang tidak memiliki kepastian nominal keuntungan yang diterima bank maupun segi waktunya melainkan hanya menyepakati porsi nisbah bagi hasil yang akan diterima karena tergantung pada keuntungan usaha. Hal ini yang menyebabkan bank syariah kurang dominan dalam menyalurkan pembiayaan bagi hasil.

Hal ini sejalan dengan penelitian Julianto dan Kardinal (2017), Rizkitasari (2017), dan Fachrurohman (2018) yang menyatakan bahwa pembiayaan bagi hasil yaitu pembiayaan mudharabah dan musyarakah tidak memiliki pengaruh terhadap Return On Asset.

\section{Pengaruh Deposito Mudharabah terhadap Return On Asset melalui Nilai Pembiayaan Bagi Hasil}

Hipotesis 6 yang diajukan pada penelitian ini adalah Deposito Mudharabah diduga memiliki berpengaruh positif signifikan terhadap ROA melalui Nilai Pembiayan Bagi Hasil. Hasil penelitian ini menunjukkan bahwa Deposito Mudharabah tidak memiliki pengaruh terhadap Return On Asset melalui Nilai Pembiayaan Bagi Hasil. Dari analisis jalur yang telah dilakukan menunjukkan bahwa pengaruh tidak langsung Deposito Mudharabah terhadap Return On Asset memiliki nilai koefisien regresi/ original sample sebesar 0.087 dan p-values sebesar 0,185 dimana lebih besar dari 0,05 dan 
nilai t statistik sebesar $1.327<1.96$. Oleh karena nilai p-values lebih besar dari 0,05 maka Hipotesis 6 ditolak. Hasil ini menunjukan bahwa Deposito Mudharabah jika mengalami kenaikan sebesar 1 satuan secara tidak langsung terhadap Return On Asset akan mengalami kenaikan sebesar 0.087 satuan. Maka dapat dikatakan bahwa tidak terdapat pengaruh signifikan antara Deposito Mudharabah terhadap Return On Asset melalui Nilai Pembiayaan Bagi Hasil.

Hal ini dapat disebabkan Deposito Mudharabah yang dihimpun oleh bank syariah lebih dominan tersalurkan pada pembiayaan murabahah yang memiliki porsi pembiayaan mencapai 59\%. Sedangkan penyaluran pada pembiayaan bagi hasil lebih sedikit yang mengakibtkan tidak berpengaruh terhadap ROA.

\section{Pengaruh NPFt-1 terhadap Return On Asset melalui Nilai Pembiayaan Bagi Hasil}

Hipotesis 7 yang diajukan pada penelitian ini adalah NPF tahun lalu diduga mempunyai pengaruh negatif terhadap Return On Asset melalui Nilai Pembiayaan Bagi Hasil. Hasil penelitian ini menunjukkan bahwa NPFt-1 tidak memiliki pengaruh terhadap Return On Asset melalui Nilai Pembiayaan Bagi Hasil. Dari analisis jalur yang telah dilakukan menunjukkan bahwa pengaruh tidak langsung NPFt-1 terhadap Return on Asset memiliki nilai koefisien regresi/ original sample sebesar 0.038 dan p-values sebesar 0.243 dimana lebih besar dari 0,05 dan nilai t statistik sebesar $1.168<$ 1.96. Oleh karena nilai p-values lebih besar dari 0,05 maka Hipotesis 7 ditolak. Hasil ini menunjukan bahwa NPFt-1 jika mengalami kenaikan sebesar 1 satuan secara tidak langsung terhadap Return On Asset akan mengalami kenaikan sebesar 0.243 satuan. Maka dapat dikatakan bahwa tidak terdapat pengaruh signifikan antara NPFt-1 terhadap Return On Asset melalui Nilai Pembiayaan Bagi Hasil.

Hal ini dapat disebabkan NPFt-1 tersebut merupakan NPF total yang sudah mencakup pembiayaan bermasalah yang berakad murabahah, mudharabah, musyarakah, ijarah dan istishna maka apabila terjadi peningkatan pembiayaan bermasalah t-1 maka akan menurunkan nilai pembiayaan murabahah. Dikarenakan pembiayaan yang memiliki porsi pembiayaan paling dominan merupakan pembiayaan berakad murabahah yang mencapai 59\% maka NPFt-1 total tidak berpengaruh melalui Nilai Pembiayaan Bagi Hasil namun berpengaruh secara langsung terhadap penurunan keuntungan yang diproyeksikan oleh Return On Asset.

\section{Penutup}

Penutup berisi hasil penelitian yang telah disarikan, terutama untuk hasil penelitian atau disarikan dari tujuan dan isi yang umum dari permasalahan yang telah diuraikan pada bagian isi. Dapat pula ditambahkan rekomendasi berdasarkan hasil penelitian yang diperoleh. (Font: Garamound, size 12, Spacing: before 4 pt; after 4 pt, Line spacing: 1)

Penulis akan menarik kesimpulan berdasarkan pada masalah yang dirumuskan pada bab satu dan hasil penelitian yang telah dibahas maka dapat ditarik kesimpulan :

1. Deposito Mudharabah berpengaruh positif signifikan terhadap Pembiayaan Bagi Hasil

NPFt-1 tidak berpengaruh terhadap Nilai Pembiayaan Bagi Hasil.

2. Deposito Mudharabah tidak berpengaruh signifikan terhadap Return On Asset. , NPFt-1 berpengaruh negatif signifikan terhadap Return On Asset.

3. Deposito Mudharabah tidak berpengaruh signifikan terhadap Return On Asset melalui Nilai Pembiayaan Bagi Hasil

4. NPFt-1 tidak berpengaruh terhadap Return On Asset melalui Nilai Pembiayaan Bagi Hasil.

Sebaiknya pembiayaan yang berakad bagi hasil dapat lebih ditingkatkan penyaluran dana nya dengan memperhatikan resiko pembiayaan dengan prinsip kehati-hatian dan Deposito Mudharabah. Diharapkan pembiayaan bagi hasil dapat menggerakan sektor riil, dikarenakan dalam pembiayaan bagi hasil dapat membentuk investasi yang sehat dan adil karena semua pihak dapat saling berbagi resiko dan kedua belah pihak mendapatkan bagi hasil keuntungan atas pembiayaan 
tersebut secara adil

Diharapkan untuk peneliti yang akan datang dapat menggunakan variabel eksternal perbankan seperti inflasi, BI Rate, SWBI, equivalent rate. Dan untuk pembiayaan yang diteliti dapat digunakan variabel pembiayaan berakad istishna, ijarah dan IMBT yang memiliki peluang bisnis yang potensial namun masih kurang diminati.

\section{Daftar Pustaka}

Agza, Yunita. 2016. Analisis Pengarub Pembiayaan Murabahah, Musyarakah, Dan Biaya Transaksi Terbadap Profitabilitas Bank Pembiayaan Rakyat Syariah. Semarang: Fakultas Ekonomika Dan Bisnis Universitas Diponegoro.

Anggraini, Dila. (2018). Pengaruh Dana Pihak Ketiga, Non Performing Financing, Tingkat Bagi Hasil dan Modal Sendiri Terhadap Profitabilitas Dengan Pembiayaan Bagi Hasil sebagai Variabel Intervening pada Perbankan Syariah. Jurnal Akuntansi Berkelanjutan Indonesia, 1(1), 122-146.

Ascarya dan Yumanita, Diana. (2005). Bank Syariah : Gambaran Umum. Jakarta: Pusat Pendidikan dan Studi Kebanksentralan (PPSK) Bank Indonesia.

Azhar, Ian dan Arim Nasim. 2016. Pengaruh Pembiayaan Jual Beli, Pembiayaan Bagi Hasil dan Non Performing Finance (Study Kasus Pada Bank Umum Syariah Di Indonesia Periode 2012 -2015). Jurnal Akuntansi Riset, 8(1), 61-76

Dewi, R. P., \& Setyowati, D. H. (2017). Faktor Penentu Pendapatan Margin Istishna pada Bank Umum Syariah di Indonesia. Jurnal Ekonomi dan Bisnis Terapan, 13(1), 31-40.

Hijriyani, N. Z., \& Setiawan, S. (2017). Analisis Profitabilitas Perbankan Syariah di Indonesia sebagai Dampak Dari Efisiensi Operasional. Jurnal Kajian Akuntansi, 1(2), 194-209

Juniarty, Nila, Mustika Noor Mifrahi, dan Achmad Tohirin. (2017). Faktor-faktor yang mempengaruhi deposito mudharabah pada bank syariah di Indonesia. Jurnal Ekonomi \& Keuangan Islam, 3(1), 36-42

Mahmoedin. (2010). Melacak Kredit Bermasalah. Cetakan Pertama. Jakarta: Pustaka Sinar Harapan

Nur'aeni, Nur'aeni, dan Setiawan, S. (2020). Third Party Funds and Non-Performing Financing for Mudharabah Financing in Indonesia's Sharia Banking. International Journal of Business, Economics, and Social Development, 1(4), 178-184.

Siregar. (2015). Metode Penelitian Kuantitaif. Jakarta: Prenadamedia Group. 